\title{
Design, Synthesis, Antihyperglycemic Studies, and Docking Simulations of Benzimidazole-Thiazolidinedione Hybrids
}

\author{
Abraham Gutierréz-Hernández, ${ }^{1}$ Yelzyn Galván-Ciprés, ${ }^{1}$ \\ Elix Alberto Domínguez-Mendoza, ${ }^{1}$ Yoshajandith Aguirre-Vidal, ${ }^{1}$ \\ Samuel Estrada-Soto $\mathbb{D}^{1}{ }^{1}$ Julio César Almanza-Pérez, ${ }^{2}$ and Gabriel Navarrete-Vázquez $\mathbb{B D}^{1}$ \\ ${ }^{1}$ Facultad de Farmacia, Universidad Autónoma del Estado de Morelos, Cuernavaca, Morelos 62209, Mexico \\ ${ }^{2}$ Depto. Ciencias de la Salud, Universidad Autónoma Metropolitana-Iztapalapa, Ciudad de México 09340, Mexico \\ Correspondence should be addressed to Gabriel Navarrete-Vázquez; gabriel_navarrete@uaem.mx
}

Received 14 August 2019; Revised 17 September 2019; Accepted 18 September 2019; Published 15 October 2019

Academic Editor: Ponnurengam Malliappan Sivakumar

Copyright (c) 2019 Abraham Gutierréz-Hernández et al. This is an open access article distributed under the Creative Commons Attribution License, which permits unrestricted use, distribution, and reproduction in any medium, provided the original work is properly cited.

\begin{abstract}
A simple and cheap three-step procedure for the synthesis of three (5Z)-5-[3(4)-(1H-benzimidazol-2-ylmethoxy)benzylidene]-1,3-thiazolidine-2,4-diones has been described via a $\mathrm{S}_{\mathrm{N}} 2$ reaction of generally recognized as safe hydroxybenzaldehydes and 2-(chloromethyl)-1H-benzimidazole, followed by a Knoevenagel condensation with thiazolidine-2,4dione in moderated yields. All the newly synthesized compounds were characterized using analytical and spectral studies. In vitro treatment on adipocytes with compounds increased the mRNA expression of two proteins recognized as strategic targets in diabetes: PPAR $\gamma$ and GLUT-4. In silico studies were conducted in order to explain the interaction binding mode of the synthesized compounds on PPAR $\gamma$. In vivo studies confirmed that compounds 1-3 have robust antihyperglycemic action linked to insulin sensitization mechanisms. The present study provides three compounds with a promising antidiabetic action.
\end{abstract}

\section{Introduction}

Type 2 diabetes is a metabolic complication depicted by a hyperglycemia $>120 \mathrm{mg} / \mathrm{dL}$, initiated by a deficiency in production or action of insulin [1]. Drugs that improve insulin resistance are effective in controlling hyperglycemia. Peroxisome proliferator-activated receptor isotype gamma $(\operatorname{PPAR} \gamma)$ is the protein target of thiazolidine-2,4-diones, a class of insulin-sensitizing drugs used as antihyperglycemic agents [2]. PPAR $\gamma$ controls target genes involved in several biological processes, for example, the facilitated glucose transporter GLUT-4 [3]. The thiazolidine-2,4-dione ring in most of the antidiabetic glitazones, such as pioglitazone and rosiglitazone, is accompanied by an additional nitrogencontaining heterocycle, for example, pyridine [4-6]. Thiazolidine-2,4-diones could be considered synthetic acid bioisosteres of natural antidiabetic p-coumaric acid $[7,8]$. Azaheterocycles such as pyridine or benzimidazole are commonly found in nature. Benzimidazole core is a natural product which is part of vitamin $B_{12}$ (Figure 1). In this work, we chose the benzimidazole azaheterocycle to generate the antihyperglycemic hybrids because this scaffold is of great importance due to its appreciated pharmacological actions in medicinal chemistry and applications in organic synthesis, acting as a privileged structure [3,9-11], which can selectively modulate diverse targets associated with the pathogenesis of diabetes. On the other hand, the election of benzylidenethiazolidine-2,4-dione as p-coumaric acid bioisostere (the major natural component widely found in grapes, red wine, tomatoes, spinach, garlic, and coffee) was taken into account because several acid bioisosteres have demonstrated antidiabetic effects [4-8].

In our current exploration on PPAR activators with antidiabetic effect, we describe in this manuscript the synthesis of hybrid benzimidazole heterocycles 1-3 containing benzylidene-1,3-thiazolidine-2,4-dione (Figure 1). Also, the 
<smiles>CCc1ccc(CCOc2ccc(CC3SC(=O)NC3=O)cc2)nc1</smiles><smiles>O=C(O)/C=C/c1ccc(O)cc1</smiles><smiles></smiles><smiles>[R]C(C)(C)OCc1nc2ccccc2[nH]1</smiles>

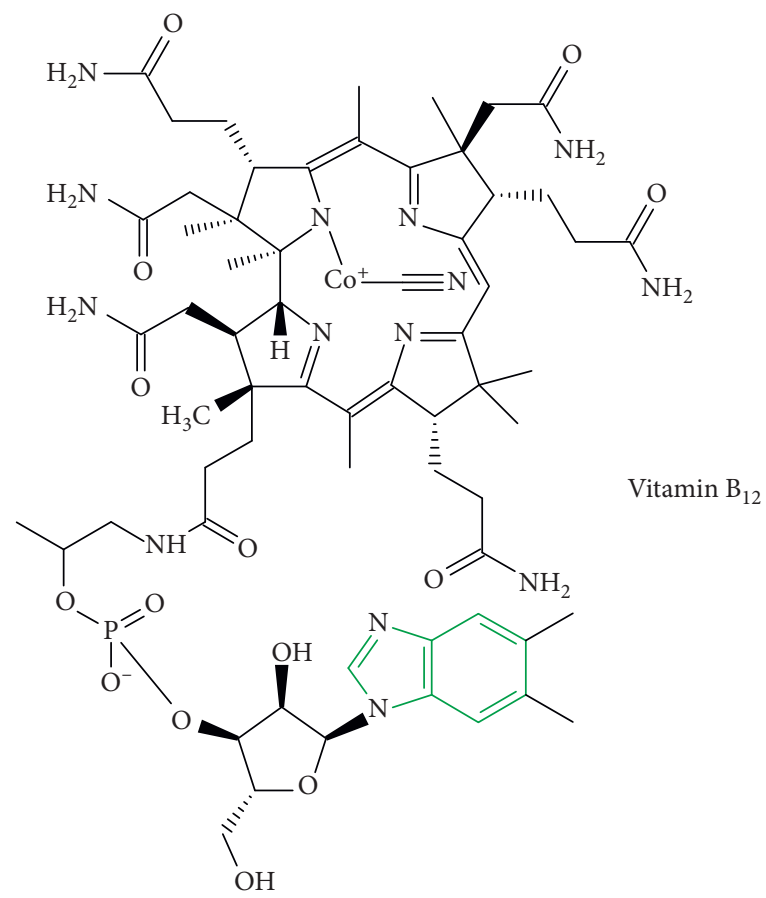

Figure 1: Antidiabetic glitazones (pioglitazone and rosiglitazone) containing pyridine and thiazolidine-2,4-dione azaheterocycles. Natural vitamin $\mathrm{B}_{12}$ containing benzimidazole azaheterocycle (green). Natural antidiabetic $p$-coumaric acid and its inspired azaheterocyclic hybrids 1-3 designed in this work.

in vitro mRNA expression of GLUT-4 and PPAR $\gamma$, in silico molecular docking simulations, and the in vivo antihyperglycemic action in a murine model have been evaluated.

\section{Materials and Methods}

2.1. Chemicals and Analytical Methods. The solvents and reagents were acquired from Sigma-Aldrich (Mexico) and were used without any further purification. Melting points were determined using an automated capillary apparatus (EZ-Melt) and are uncorrected. Chemical structures were confirmed using ${ }^{1} \mathrm{H}$ and ${ }^{13} \mathrm{C}$ NMR spectral data, employing Varian Oxford $(400 \mathrm{MHz})$ and $(100 \mathrm{MHz})$ instruments, respectively. Mass spectra were recorded on a JEOL JM(S)700 instrument, and elemental analyses have been performed using Elementar Vario ELIII instrument.
2.2. General Preparation of the Titled Compounds 1-3. In a stirred round bottom flask equipped with Dean-Stark apparatus for water removal and condenser, alkoxybenzaldehydes 5-7 ( $0.3 \mathrm{~g}, 0.8 \mathrm{mmol})$, benzoic acid $(0.03 \mathrm{~g}$, $0.24 \mathrm{mmol}, 30 \%)$, and piperidine $(0.025 \mathrm{~mL}, 0.24 \mathrm{mmol}$, $30 \%)$ were dissolved in dry toluene $(10 \mathrm{~mL})$. The mixture was heated to $40^{\circ} \mathrm{C}$ for $10 \mathrm{~min}$. Thiazolidine-2,4-dione $(0.11 \mathrm{~g}$, $0.9 \mathrm{mmol}, 1.1$ equiv.) was added, and the mixture was refluxed for $7 \mathrm{~h}$. The reaction was monitored by thin-layer chromatography. After complete conversion, the resulting solids were filtered, washed with cold toluene, dried, and recrystallized from adequate solvents.

2.2.1. (5Z)-5-[4-(1H-Benzimidazol-2-ylmethoxy)benzylidene]1,3-thiazolidine-2,4-dione (1). Yellow pale powder, $\mathrm{mp}$ $255^{\circ} \mathrm{C}-258.3^{\circ} \mathrm{C}$; yield 76.3\%. ${ }^{1} \mathrm{H}$ NMR $\left(400 \mathrm{MHz}, \mathrm{DMSO}-d_{6}\right)$

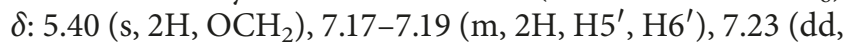


$2 \mathrm{H}, \mathrm{H}-3, \mathrm{H}-5, J m=1.2, J o=8.8 \mathrm{~Hz}), 7.55-7.57\left(\mathrm{~m}, 2 \mathrm{H}, \mathrm{H}-4^{\prime}\right.$, $\left.\mathrm{H}-7^{\prime}\right), 7.57(\mathrm{dd}, 2 \mathrm{H}, \mathrm{H}-2, \mathrm{H}-6, J m=1.2, J o=8.8 \mathrm{~Hz}), 7.67(\mathrm{~s}$, $1 \mathrm{H},=\mathrm{C}-\mathrm{H})$, and $12.68(\mathrm{~s}, 1 \mathrm{H}, \mathrm{N}-\mathrm{H}) \mathrm{ppm} .{ }^{13} \mathrm{C} \mathrm{NMR}$ $\left(100 \mathrm{MHz}, \mathrm{DMSO}-d_{6}\right) \delta: 64.4\left(\mathrm{OCH}_{2}\right), 116.1\left(\mathrm{C}-3, \mathrm{C}-5, \mathrm{C}-4^{\prime}\right.$, C-7'), $122.4\left(\mathrm{C}-5^{\prime}, \mathrm{C}^{\prime} 6^{\prime}\right), 123.1$ (=C-), $127.1(\mathrm{C}-1), 130.7$ (=C-H), 132.3 (C-2, C-6), $138.6\left(\mathrm{C}-3 \mathrm{a}^{\prime}, \mathrm{C}-7 \mathrm{a}^{\prime}\right), 150.1\left(\mathrm{C}-2^{\prime}\right)$, 159.7 (C-4), $168.1(\mathrm{~N}-\mathrm{C}=\mathrm{O}), 171.1(\mathrm{~S}-\mathrm{C}=\mathrm{O})$ ppm; MS/EI: $\mathrm{m} /$ $z$ (\% int. rel). $351\left(\mathrm{M}^{+}, 1 \%\right)$, and $259(100 \%)$. Anal. calcd. for $\mathrm{C}_{18} \mathrm{H}_{13} \mathrm{~N}_{3} \mathrm{O}_{3} \mathrm{~S}$ : C 61.53, H 3.73, N 11.96, S 9.13; found $\mathrm{C}$ 61.50, H 3.68, N 11.87, S 9.19.

2.2.2. (5Z)-5-[4-(1H-Benzimidazol-2-ylmethoxy)-3-methoxybenzylidene]-1,3-thiazolidine-2,4-dione (2). Yellow powder, $\mathrm{mp}$ 245.8-248. $7^{\circ} \mathrm{C}$; yield $85.5 \% .{ }^{1} \mathrm{H}$ NMR $(400 \mathrm{MHz}$, DMSO- $\left.d_{6}\right) \delta: 3.80\left(\mathrm{~s}, 3 \mathrm{H}, \mathrm{OCH}_{3}\right), 5.36\left(\mathrm{~s}, 2 \mathrm{H}, \mathrm{OCH}_{2}\right), 7.14$ (d, 2H, H-5' , H-6' Jo = 8.4 Hz), 7.18-7.20 (m, 2H, H-2, H-6), $7.30(\mathrm{~d}, 1 \mathrm{H}, \mathrm{H}-5, J o=8.8 \mathrm{~Hz}), 7.55-7.57\left(\mathrm{~m}, 2 \mathrm{H}, \mathrm{H}-4^{\prime}, \mathrm{H}-7^{\prime}\right)$, $7.71(\mathrm{~s}, 1 \mathrm{H},=\mathrm{C}-\mathrm{H})$, and $12.68(\mathrm{~s}, 1 \mathrm{H}, \mathrm{N}-\mathrm{H}) \mathrm{ppm} .{ }^{13} \mathrm{C} \mathrm{NMR}$ $\left(100 \mathrm{MHz}, \mathrm{DMSO}-d_{6}\right) \delta: 55.7\left(\mathrm{OCH}_{3}\right), 64.7\left(\mathrm{OCH}_{2}\right), 113.9$ (C-5), 114.1 (C-2), 121.17 (=C-), 123.8 (=C-H), 127.1 (C-6), 128.6 (C-4', C-7'), 129.1 (C-5', C-6'), 132.1 (C-1), 138.6 (C$\left.3 \mathrm{a}^{\prime}, \mathrm{C}-7 \mathrm{a}^{\prime}\right), 149.8(\mathrm{C}-4), 149.8(\mathrm{C}-3), 149.5\left(\mathrm{C}-2^{\prime}\right), 168.1(\mathrm{~N}-$ $\mathrm{C}=\mathrm{O})$, and $168.6(\mathrm{~S}-\mathrm{C}=\mathrm{O}) \mathrm{ppm}$; MS/EI: $m / z$ (\% int. rel). 381 $\left(\mathrm{M}^{+}, 1 \%\right), 265(80 \%)$, and $180(100 \%)$. Anal. calcd. for $\mathrm{C}_{19} \mathrm{H}_{15} \mathrm{~N}_{3} \mathrm{O}_{4} \mathrm{~S}: \mathrm{C} 59.83, \mathrm{H} 3.96, \mathrm{~N} 11.02$, S 8.41; found $\mathrm{C}$ 59.90, H 3.89, N 11.00, S 8.45.

2.2.3. (5Z)-5-[3-(1H-Benzimidazol-2-ylmethoxy)-4-methoxybenzylidene-1,3-thiazolidine-2,4-dione (3). Yellow powder, mp $246.9^{\circ} \mathrm{C}(\mathrm{dec})$; yield $31 \% .{ }^{1} \mathrm{H}$ NMR $(400 \mathrm{MHz}$, DMSO- $\left.d_{6}\right) \delta: 3.85\left(\mathrm{~s}, 3 \mathrm{H}, \mathrm{OCH}_{3}\right), 5.34\left(\mathrm{~s}, 2 \mathrm{H}, \mathrm{OCH}_{2}\right), 7.17(\mathrm{~s}$, $1 \mathrm{H}, \mathrm{H}-5, J o=8.6 \mathrm{~Hz}), 7.18-7.20\left(\mathrm{~m}, 2 \mathrm{H}, \mathrm{H}-5^{\prime}, \mathrm{H}-6^{\prime}\right), 7.23$ $(\mathrm{dd}, 1 \mathrm{H}, \mathrm{H}-6, \mathrm{Jm}=1.02, J o=8.6 \mathrm{~Hz}), 7.37(\mathrm{~d}, 1 \mathrm{H}, \mathrm{H}-2$, $J m=1.02 \mathrm{~Hz}), 7.56-7.58\left(\mathrm{~m}, 2 \mathrm{H}, \mathrm{H}-4^{\prime}, \mathrm{H}-7^{\prime}\right), 7.69(\mathrm{~s}, 1 \mathrm{H}$, $=\mathrm{C}-\mathrm{H})$, and $12.68(\mathrm{~s}, 1 \mathrm{H}, \mathrm{N}-\mathrm{H}) \mathrm{ppm} .{ }^{13} \mathrm{C}$ NMR $(100 \mathrm{MHz}$, DMSO- $\left.d_{6}\right) \delta: 55.7\left(\mathrm{OCH}_{3}\right), 64.4\left(\mathrm{OCH}_{2}\right), 112.5(\mathrm{C}-5), 115.2$ (C-2), 122.1 (=C-), 124.6 (C-6), 125.7 (=C-H), 128.5 (C-4', C-7'), $129.2\left(\mathrm{C}-5^{\prime}, \mathrm{C}-6^{\prime}\right), 131.3(\mathrm{C}-1), 138.6\left(\mathrm{C}-3 \mathrm{a}^{\prime}, \mathrm{C}-7 \mathrm{a}^{\prime}\right)$, $147.5(\mathrm{C}-3), 149.5(\mathrm{C}-4), 150.1\left(\mathrm{C}-2^{\prime}\right), 168.4(\mathrm{~N}-\mathrm{C}=\mathrm{O})$, and 168.8 (S-C=O) ppm; MS/EI: $m / z$ (\% int. rel). $381\left(\mathrm{M}^{+}, 1 \%\right)$, anal. calcd. for $\mathrm{C}_{19} \mathrm{H}_{15} \mathrm{~N}_{3} \mathrm{O}_{4} \mathrm{~S}$ : C 59.83, H 3.96, N 11.02, S 8.41; found C 59.76, H 3.89, N 11.00, S 8.36.

2.3. Preparation of 2-(Chloromethyl)-1H-benzimidazole (4). 1,2-Phenylenediamine $(1 \mathrm{~g}, 0.8 \mathrm{mmol}), 1.3$ equivalents of chloroacetic acid, and $10 \mathrm{~mL}$ of $1 \mathrm{M} \mathrm{HCl}$ were heated at $90^{\circ} \mathrm{C}$ in a nitrogen atmosphere for $10 \mathrm{~h}$. The cooled mixture was basified with saturated $\mathrm{NaHCO}_{3}$ solution, and the crude product was extracted with AcOEt. Solvent was removed and the solids filtrated. Yellow powder, $\mathrm{mp} 147.8-148.2^{\circ} \mathrm{C}$ (Lit. $142^{\circ} \mathrm{C}-144^{\circ} \mathrm{C}$ ); yield $53.2 \% .{ }^{1} \mathrm{H}$ NMR $(400 \mathrm{MHz}$, DMSO- $\left.d_{6}\right) \delta: 4.90\left(\mathrm{~s}, 2 \mathrm{H}, \mathrm{ClCH}_{2}\right), 7.18-7.20\left(\mathrm{~m}, 2 \mathrm{H}, \mathrm{H}-5^{\prime}\right.$, H-6 $6^{\prime}$, and 7.54-7.55 (m, 2H, H-4 $\left.4^{\prime}, \mathrm{H}-7^{\prime}\right)$ ppm. MS/EI: $m / z$ (\% int. rel). $165\left(\mathrm{M}^{+}, 45 \%\right), 131(100 \%)$, and $180(100 \%)$.

2.4. General Preparation of Precursors 5-7. A solution of generally recognized as safe hydroxybenzaldehydes $(0.25 \mathrm{mmol}$ of 4-hydroxybenzaldehyde (8), vanillin (9), or isovanillin (10)) and $\mathrm{K}_{2} \mathrm{CO}_{3}(0.51 \mathrm{mmol}, 2$ equiv.) in $5 \mathrm{~mL}$ of acetonitrile was heated at $50^{\circ} \mathrm{C}$ for $30 \mathrm{~min}$. After that, 2-(chloromethyl)- $1 \mathrm{H}$ benzimidazole (4) $(0.275 \mathrm{mmol}, 1.1$ equiv. $)$ in acetonitrile was added drop by drop. The reaction was heated for $2-9 \mathrm{~h}$. Acetonitrile was removed using a rotavapor. $10 \mathrm{~mL}$ of ice-water was added and stirred for $10 \mathrm{~min}$. The emulsion was extracted with $\mathrm{EtAcO}(3 \times 15 \mathrm{~mL})$, and the organic layer was evaporated to give a solid, which was recrystallizated from suitable solvent.

2.4.1. 4-(1H-Benzimidazol-2-ylmethoxy)benzaldehyde (5). Brown powder, ethanol, mp $179^{\circ} \mathrm{C}-181.9^{\circ} \mathrm{C}$; yield $95 \% .{ }^{1} \mathrm{H}$ NMR $\left(400 \mathrm{MHz}, \mathrm{DMSO}-d_{6}\right) \delta: 5.45\left(\mathrm{~s}, 2 \mathrm{H}, \mathrm{OCH}_{2}\right), 7.17-$ 7.20 (m, 2H, H-5', H-6'), 7.29 (dd, 2H, H-3, H-5, Jm = 1.2, $J o=8.8 \mathrm{~Hz}), 7.54-7.56\left(\mathrm{~m}, 2 \mathrm{H}, \mathrm{H}-4^{\prime}, \mathrm{H}-7^{\prime}\right), 7.88(\mathrm{dd}, 2 \mathrm{H}$, $\mathrm{H}-2, \mathrm{H}-6, \mathrm{Jm}=1.2, \mathrm{Jo}=8.8 \mathrm{~Hz}$ ), and 9.87 (s, 1H, CHO) ppm. MS/EI: $m / z$ (\% int. rel). $252\left(\mathrm{M}^{+}, 24 \%\right)$ and $131(100 \%)$.

2.4.2. 4-(1H-Benzimidazol-2-ylmethoxy)-3-methoxybenzaldehyde (6). Brown powder, ethanol, mp 71.7-74.7 ; yield $48.7 \%{ }^{1} \mathrm{H}$ NMR (400 MHz, DMSO- $\left.d_{6}\right) \delta: 3.82\left(\mathrm{~s}, 3 \mathrm{H}, \mathrm{OCH}_{3}\right), 5.41(\mathrm{~s}$, $2 \mathrm{H}, \mathrm{OCH}_{2}$ ), 7.16-7.18 (m, 2H, H-5', H-6 $\left.{ }^{\prime}\right), 7.37$ (d, 1H, H-5, $J o=8.8 \mathrm{~Hz}), 7.41(\mathrm{~d}, 1 \mathrm{H}, \mathrm{H}-2, J m=2.1 \mathrm{~Hz}), 7.53(\mathrm{dd}, 1 \mathrm{H}, \mathrm{H}-6$, $J m=2.1, J o=8.8 \mathrm{~Hz}), 7.53-7.55\left(\mathrm{~m}, 2 \mathrm{H}, \mathrm{H}-4^{\prime}, \mathrm{H}-7^{\prime}\right)$, and 9.83 (s, $1 \mathrm{H}, \mathrm{CHO})$ ppm. MS/EI: $m / z$ (\% int. rel) $282\left(\mathrm{M}^{+}, 1 \%\right)$ and $131(100 \%)$.

2.4.3. 3-(1H-Benzimidazol-2-ylmethoxy)-4-methoxybenzaldehyde (7). Brown powder, ethanol, $\mathrm{mp} 80.9^{\circ} \mathrm{C}$ (dec); yield 59\%. ${ }^{1} \mathrm{H}$ NMR (400 MHz, DMSO-d $)_{6} \delta: 3.89$ (s, 3H, $\mathrm{OCH}_{3}$ ), 5.37 (s, $\left.2 \mathrm{H}, \mathrm{OCH}_{2}\right), 7.13(\mathrm{~d}, 1 \mathrm{H}, \mathrm{H}-5, J o=8.7 \mathrm{~Hz}), 7.19\left(\mathrm{~m}, 2 \mathrm{H}, \mathrm{H}-4^{\prime}\right.$, H-7'), 7.23 (d, 1H, H-6 Jo=8.7 Hz), 7.37 (s, 1H, H-2), and 9.82 (s, 1H, CHO) ppm. MS/EI: $m / z$ (\% int. rel) $282\left(\mathrm{M}^{+}, 2 \%\right)$ and $131(100 \%)$.

\subsection{Biological Activity}

2.5.1. PPAR $\gamma$ and GLUT-4 Determination. Assays were performed as described elsewhere [3, 12, 13]. Briefly, 3T3L1 murine fibroblasts were cultured, and cell viability was measured using the MTT assay at three increasing concentrations $(1,10$, and $100 \mu \mathrm{M})$ of hybrids 1-3. Confluent cultures of fibroblasts were differentiated to the adipocyte phenotype for $48 \mathrm{~h}$ employing $0.5 \mathrm{mM}$ of 3-isobutyl-1methylxanthine, $0.25 \mu \mathrm{M}$ of dexamethasone acetate, and $0.8 \mu \mathrm{M}$ of murine insulin, enriched by additional insulin charge. After 8 to 10 days, the cells acquire the mature adipocyte phenotype and were treated for $24 \mathrm{~h}$ to observe the effects of heterocycles $\mathbf{1 - 3}$ on PPAR $\gamma$ and GLUT-4 mRNA expression. Total mRNA was isolated from adipocytes, and $2 \mu \mathrm{g}$ was reverse transcribed. The cDNA was amplified using SYBR Green Master Mix (Roche) containing $0.5 \mathrm{mM}$ of customized primers for PPAR $\gamma$ (GenBank accession no.: NM 011146.1) and GLUT-4 (GenBank accession no.: NM009204.2). PCR was used for individually sample calculating the threshold cycles $\left(C_{\mathrm{t}}\right)$ and the $\Delta C_{\mathrm{t}}$ values. The amount of mRNA for each gene was normalized 
according to the amount of mRNA encoding ribosomal protein 36B4 (GenBank accession no.: NM_007475.2). The $\Delta C_{\mathrm{t}}$ values were calculated in every sample for each gene of interest as follows: $C_{\mathrm{t}}$ gene of interest $-C_{\mathrm{t}}$ reference gene with $36 \mathrm{~B} 4$ as the reference gene (mRNA of reference remained stable throughout the experiments). Fluctuations in the relative expression levels of individual specific genes $\left(\Delta \Delta C_{\mathrm{t}}\right)$ were measured and graphed $[2,12]$.

2.5.2. In Vivo Oral Glucose Tolerance Assay. All animal procedures were conducted in accordance with the Official Mexican Rules for Animal Experimentation and Care (SAGARPA, NOM-062-ZOO-1999), ratified by the Institutional Animal Care and Use Committee of the Universidad Autónoma Metropolitana (dictum 1857), based on US National Institutes of Health Publication \#85-23, revised 1985.

Normoglycemic mice (ICR strain) were divided into 3 groups of 6 mice $(n=6) .30$ minutes after administration of heterocycles 1-3, a dose of $2 \mathrm{~g} / \mathrm{kg}$ of glucose solution was administered to individual mouse. Samples of blood were collected from the caudal vein at $0,0.5,1,1.5$, and 2 hours, followed by the oral administration of vehicle (Tween 80 , $10 \%$ ), heterocycles 1-3, or glibenclamide. Glucose concentration was estimated using a commercial glucometer test strips $[3,12]$.

2.6. Statistical Analysis. To analyze the fluctuations in the percent variation of plasmatic glucose and the in vitro PPAR $\gamma$ and GLUT-4 determinations, we employed ANOVA, complemented with a Dunnett's multiple test. All values are expressed as the mean \pm SEM, $p<0.05$ (statistically significant). GraphPad Prism 5.0 was used for the analysis.

2.7. In Silico Docking Calculations. Molecular operation environment software (MOE) [14] and Pymol version 1.0 were employed for visualization. The crystal coordinates of PPAR $\gamma$ were retrieved from the protein databank (PDB) with the accession code 5U5L. Docking simulations were performed with AutoDock, ver.4.2. The program conducts numerous runs in each docking experiment. $\mathrm{H}_{2} \mathrm{O}$ molecules and cocrystal ligands were extracted from the crystallographic coordinates, and Gasteiger charges were assigned for the compounds and PPAR $\gamma$. All torsions were permitted to rotate during the calculation. The program AutoGrid created the grid maps, placed at the coordinates of the crystallographic ligand with dimensions of $60 \times 60 \times 60 \AA$ and points separated by $0.375 \AA$. The number of docking runs was 100 . After computational calculations, all solutions were clustered into groups with RMSD $<2.0 \AA$ and by the lowest energy.

2.7.1. Docking Validation. The docking protocols were validated by redocking of rivoglitazone (cocrystal ligand) into the PPAR $\gamma$ ligand binding site of $5 \mathrm{U} 5 \mathrm{~L}$. The root mean square deviation (RMSD) between the cocrystal ligand and the rivoglitazone docked was $0.433 \AA$. This value specifies that the parameters for docking calculations are reproducing conformation and orientation in the X-ray crystal of PPAR $\gamma$.

\section{Results and Discussion}

3.1. Chemistry. The synthetic route for the preparation of hybrid compounds 1-3 is described in Figure 2. For achieving the synthesis of the titled compounds involved the preliminary preparation of 2-chloromethyl-1H-benzimidazole (4). In this step, starting from 1,2-phenylenediamine (13) upon treating with chloroacetic acid (12) in $10 \mathrm{~mL}$ of $\mathrm{HCl} 1 \mathrm{M}$ as solvent generated 4 in moderated yield (53\%). Later, the aforementioned reaction mixture was heated in acetonitrile with 4-hydroxybenzaldehyde (8), vanillin (9), or isovanillin (10), three generally recognized as safe compounds, in the presence of anhydrous $\mathrm{K}_{2} \mathrm{CO}_{3}$, yielded alkoxybenzaldehydes 5-7. In the last step, a mixture of alkoxybenzaldehydes $\mathbf{5 - 7}$, piperidinium benzoate (30\% $\mathrm{mol}$ ), and thiazolidine-2,4-dione (11), in toluene was heated under reflux with constant elimination of $\mathrm{H}_{2} \mathrm{O}$ employing a Dean-Stark apparatus. After the reaction was completed by TLC, the mixture was cooled to room temperature and the solids were separated by filtration affording the corresponding compounds 1-3, which were recovered with $31-85 \%$ yields and purified by recrystallization. Chemical structures were established by spectroscopic $\left({ }^{1} \mathrm{H},{ }^{13} \mathrm{C}\right.$ NMR $)$ and spectrometric analysis. In the nuclear magnetic resonance spectra, the signals of the respective hydrogens of the titled heterocycles were assigned identifying the chemical shifts, multiplicities, and coupling constants $(J)$. All compounds exhibited a single signal ranging from $\delta_{\mathrm{H}} 5.34$ to $5.40 \mathrm{ppm}$, attributed to $\mathrm{CH}_{2}$ of the ether bridge. Compounds $\mathbf{2}$ and $\mathbf{3}$ displayed the characteristic signals of trisubstituted benzene, whereas compound 1 showed signals for disubstituted benzene. The aromatic region of the ${ }^{1} \mathrm{H}$ NMR spectrum of compounds 1-3 contained an $\mathrm{A}_{2} \mathrm{~B}_{2}$ pattern signals ranging from $\delta_{\mathrm{H}} 7.14$ to $7.20 \mathrm{ppm}\left(\mathrm{d}, J_{\mathrm{ortho}}=8.4 \mathrm{~Hz}\right)$ and 7.55 to $7.58 \mathrm{ppm}\left(\mathrm{d}, J_{\text {ortho }}=8.4 \mathrm{~Hz}\right.$ ) attributed to the equivalents $\mathrm{H}-5^{\prime}, \mathrm{H}-6^{\prime}$ and $\mathrm{H}-4^{\prime}, \mathrm{H}-\mathrm{7}^{\prime}$, respectively, of the benzimidazole tautomeric ring. The displacement for methoxy group in compounds $\mathbf{2}$ and $\mathbf{3}$ was found in 3.80 and $3.85 \mathrm{ppm}$ (singlet), respectively. In all compounds, a singlet signal for benzylidene hydrogen was found ranging from $\delta_{\mathrm{H}}$ 7.67 to $7.71 \mathrm{ppm}$, and the last signal of the spectra was found in $12.68 \mathrm{ppm}$, corresponding to N-H of the thiazolidine-2,4dione ring. For the ${ }^{13} \mathrm{C}$ nuclear magnetic resonance spectra, constant signals were found for the benzimidazole nucleus: one signal ranging from $\delta_{\mathrm{C}} 116.1$ to $128.7 \mathrm{ppm}$, attributed to $\mathrm{C}-4^{\prime}$ and $\mathrm{C}-7^{\prime}$, and additional signal ranging from $\delta_{\mathrm{C}} 122.4$ to $129.2 \mathrm{ppm}$, assigned to $\mathrm{C}-5^{\prime}$ and $\mathrm{C}-6^{\prime}$. Another frequent signal was found in downfield shifts from $\delta_{\mathrm{C}} 149.5$ to $150.1 \mathrm{ppm}$ endorsed to $\mathrm{C}-2^{\prime}$, found in all compounds. The thiazolidine-2,4-dione scaffold also showed constant signals: $\delta_{\mathrm{C}} 168.6$ to $171.1 \mathrm{ppm}$ attributed to $\mathrm{S}-\mathrm{C}=\mathrm{O}, \delta_{\mathrm{C}} 168.1$ to $168.6 \mathrm{ppm}$ endorsed to $\mathrm{N}-\mathrm{C}=\mathrm{O}$, and $\delta_{\mathrm{C}} 121.1$ to $123.1 \mathrm{ppm}$ assigned to $=\mathrm{C}$-S. Benzylidene signal was found in $\delta_{\mathrm{C}} 123.8$ 


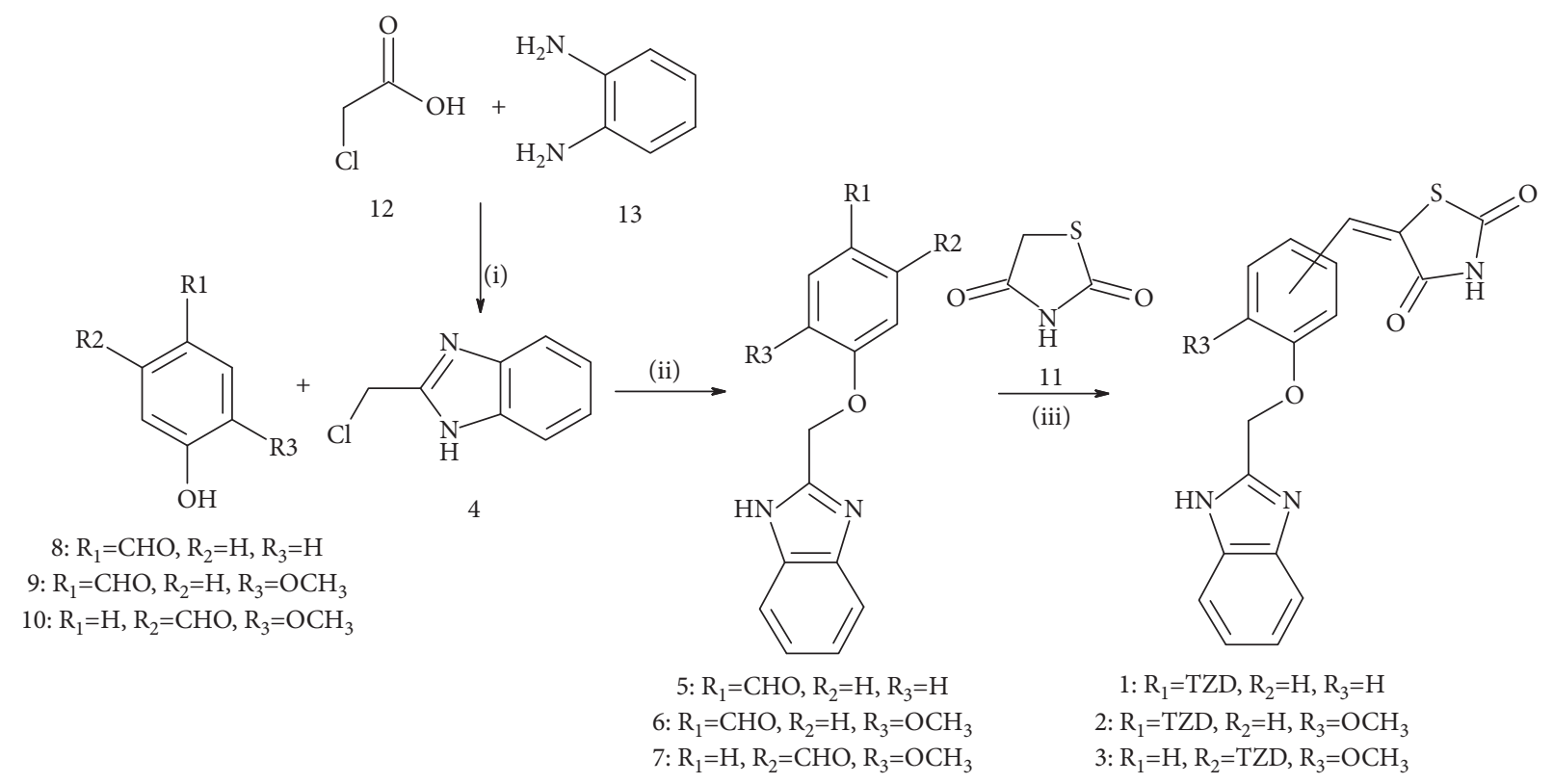

FIgURE 2: Synthesis of compounds 1-3: (i) $\mathrm{HCl} 1 \mathrm{M}$ reflux; (ii) $\mathrm{K}_{2} \mathrm{CO}_{3}$, acetonitrile; (iii) piperidinium benzoate (30\% mol), toluene, and Dean-Stark apparatus.

to $130.7 \mathrm{ppm}$, whereas the signal for methyleneoxy bridge was constant in 64.4 to $64.7 \mathrm{ppm}$.

3.2. In Vitro mRNA Expression of PPAR $\gamma$ and GLUT-4. For the in vitro mRNA expression of selected targets, murine fibroblasts (3T3-L1) were differentiated to adipocytes to observe the effect of title compounds on PPAR $\gamma$ and GLUT4 mRNA concentration. Adipocytes were processed for 24 hours with $10 \mu \mathrm{M}$ of heterocycles 1-3 and agonist control drug (pioglitazone, PIO) $[12,13]$. Previously, the viability of 3T3-L1 cells was examined at 1,10 , and $100 \mu \mathrm{M}$ of compounds 1-3 using the MTT assay reported in reference [15]. No cytotoxicity was observed in any of the three concentrations tested (data not shown). Then, fluctuation in the mRNA expression level was evaluated by qPCR. Figure 3 shows that compounds 2, 3, and pioglitazone (PIO) augmented with statistical significance, the mRNA expression of PPAR $\gamma$ (around 2.7- to 3.2-fold), and its downstream gene GLUT-4 (3.5-fold). On the other hand, the increased levels of PPAR $\gamma$ and another glucose transporter (GLUT-2) were previously reported for $p$-coumaric acid $[7,8]$.

Agonism of PPAR $\gamma$ could decrease glycemia in diabetic individuals through an improvement in insulin sensitization, and the increments in GLUT-4 levels in the striated muscle are crucial for glucose regulation [16]. The results obtained here suggest that compounds $\mathbf{2}$ and $\mathbf{3}$ prompt GLUT-4 mRNA concentration greater than pioglitazone (Figure 3(b)).

Furthermore, compound $\mathbf{1}$ did not provoke a statistically significant rise in the mRNA expression level of PPAR $\gamma$, but a slight increase in GLUT-4 expression (2.1-fold). These results suggest that increments in the concentration of the downstream genes are not always dependent on high expression of PPAR $\gamma$, instead the activation is the most important process.

3.3. In Vivo Oral Glucose Tolerance Test (OGTT). To confirm the possible hypoglycemic and/or antihyperglycemic action of hybrids 1-3, we performed an OGTT in normal glycemic mice using glibenclamide (Gli) as hypoglycemic control drug. Figure 4 shows the results of these experiments. All compounds administered at $100 \mathrm{mg} / \mathrm{kg}$ significantly decreased glycemia sixty minutes after glucose ingestion ( $2 \mathrm{~g} /$ $\mathrm{kg}$ ) in comparison with the vehicle (Tween $80,10 \%$ ) that showed the maximum hyperglycemia at the first hour. The AUC graph (area under the curve) established the efficacy of heterocycles 1-3, which decreased with statistical significance the AUC of the control (vehicle) around 75\% (Figure 4). Throughout the assay, glucose concentrations did not diminish beyond normal levels as glibenclamide did, demonstrating that compounds $\mathbf{1 - 3}$ have an antihyperglycemic effect in agreement with insulin sensitization provoked by PPAR agonism [16, 17].

3.4. Molecular Docking Simulations. Once established the in vitro PPAR activation and in vivo antihyperglycemic action, compounds 1-3 were subjected to an in silico docking analysis, in order to explain the experimental effects on PPAR $\gamma$. Docking simulation exposed that hybrids 1-3 enter into the ligand binding site of PPAR $\gamma$ (PDB ID: 5U5L) and produce a net of hydrogen bonds with His-323, and several contact with Tyr-327, Cys-285, Ser-289, and Arg-288, the important amino acids for the PPAR $\gamma$ activation (Figure 5). Rivoglitazone was previously cocrystallized with PPAR $\gamma$ and shared the same contacts, where only one oxygen atom from the thiazolidine-2,4-dione participates in the hydrogen- 


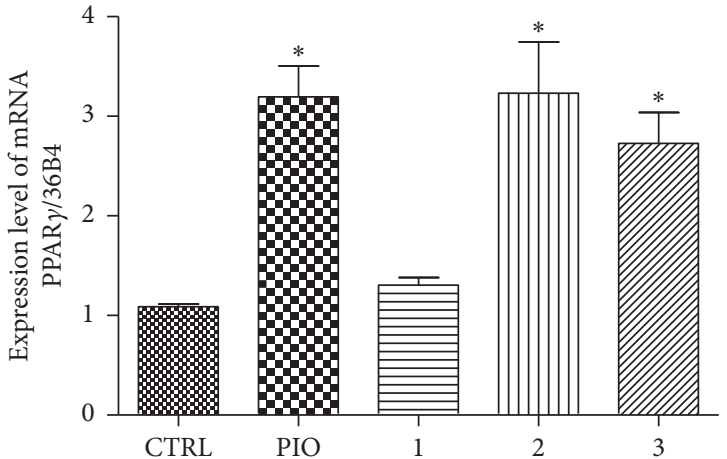

(a)

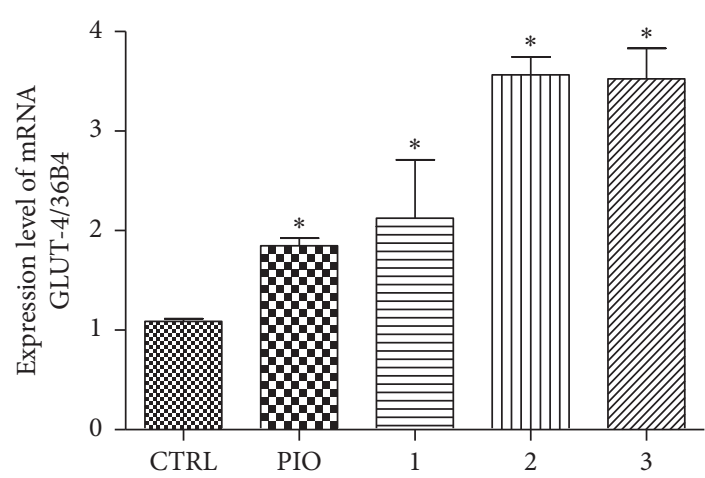

(b)

FIGURE 3: Changes in the expression of PPAR $\gamma$ (a) and GLUT-4 (b) induced by hybrid bioisosteres 1-3 and pioglitazone. ANOVA with post hoc Dunnett's test $(n=5$, mean \pm SEM, $p<0.001$ compared with CTRL group).

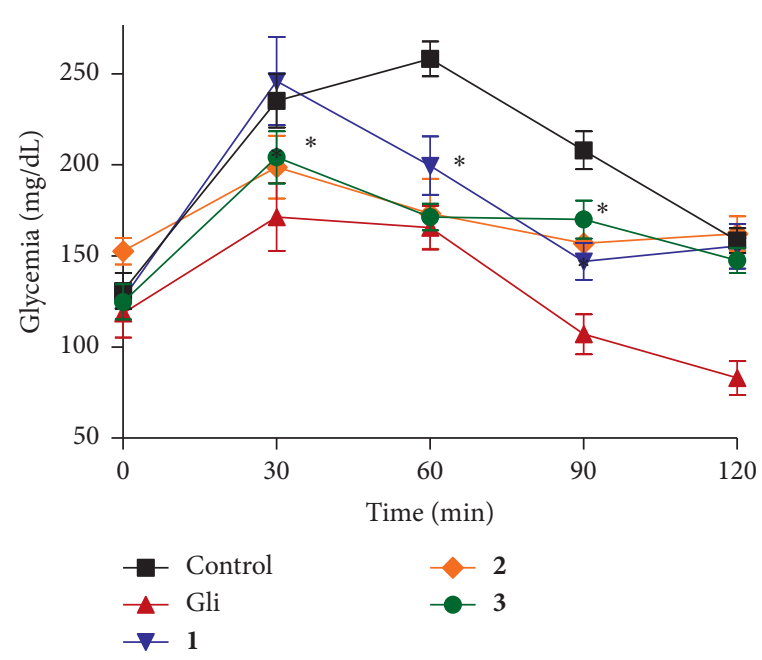

(a)

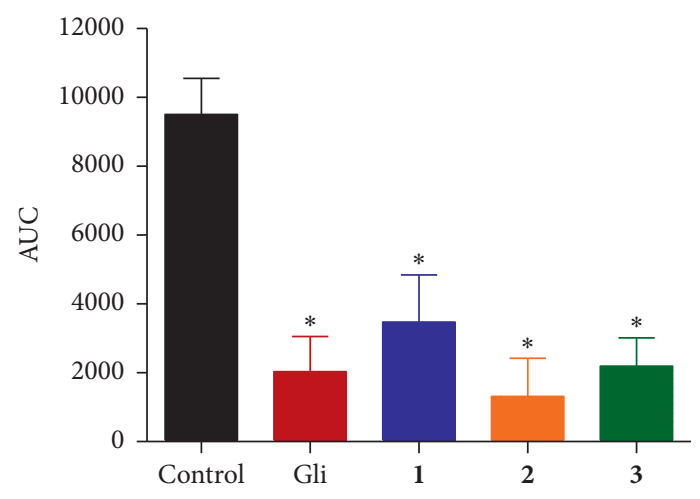

(b)

Figure 4: Oral glucose tolerance test (a) and AUC (b) of heterocycles 1-3. ${ }^{*}$ Statistical significance compared with control $(n=6$, mean \pm SEM, $p<0.05)$.

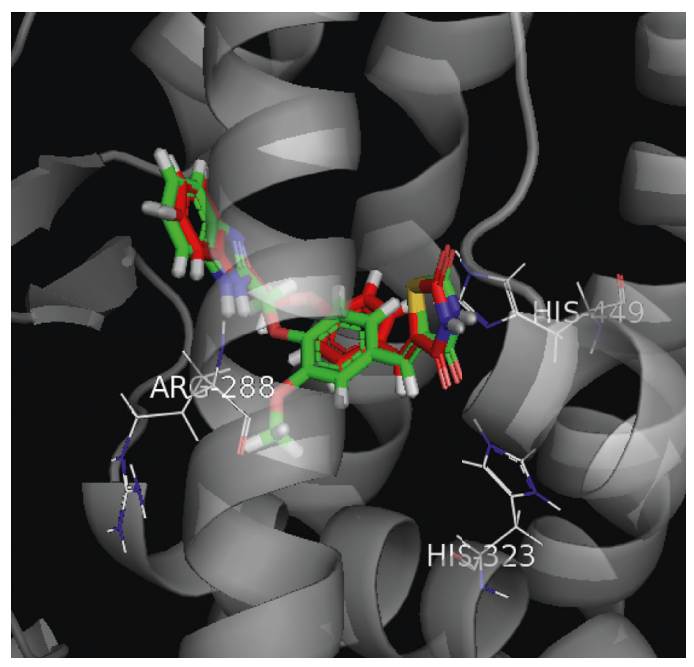

(a)

va1

Met

(11)

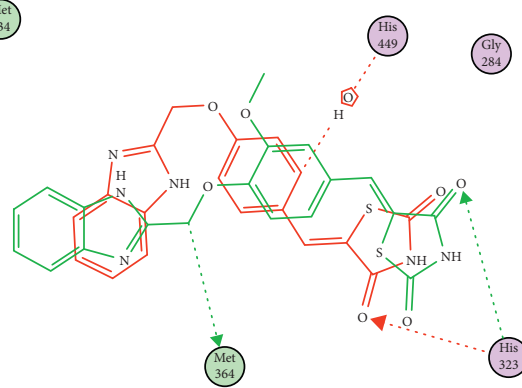

(2401)<smiles></smiles>

(iin)

(II)

(II)

(Le1

(Phe

(1112

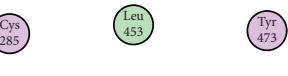

(b)

Figure 5: 3-D binding diagram (a) and 2-D overlay (b) of 1 (red) and 2 (green) into the PPAR $\gamma$ ligand site, sharing the same orientation. 
TABLE 1: Molecular docking binding energies, calculated affinities, and qualitative pharmacological activities of compounds 1-3.

\begin{tabular}{lcccc}
\hline Compound & PPAR $\gamma \Delta \mathrm{G}(\mathrm{kcal} / \mathrm{mol})$ & Ki $(\mu \mathrm{M})$ & In vitro activity & In vivo effect \\
\hline $\mathbf{1}$ & -7.98 & 1.346 & ++ & ++ \\
$\mathbf{2}$ & -8.17 & 0.976 & ++ & ++ \\
$\mathbf{3}$ & -8.96 & 0.256 & ++ & ++ \\
p-Coumaric acid* & -4.64 & 385.9 & $+[8]$ & ++ \\
Rivoglitazone* $^{*}$ & -7.33 & 4.261 & $++[6]$ & $+[8]$ \\
\hline
\end{tabular}

${ }^{*}$ References [6], [8], and [18].

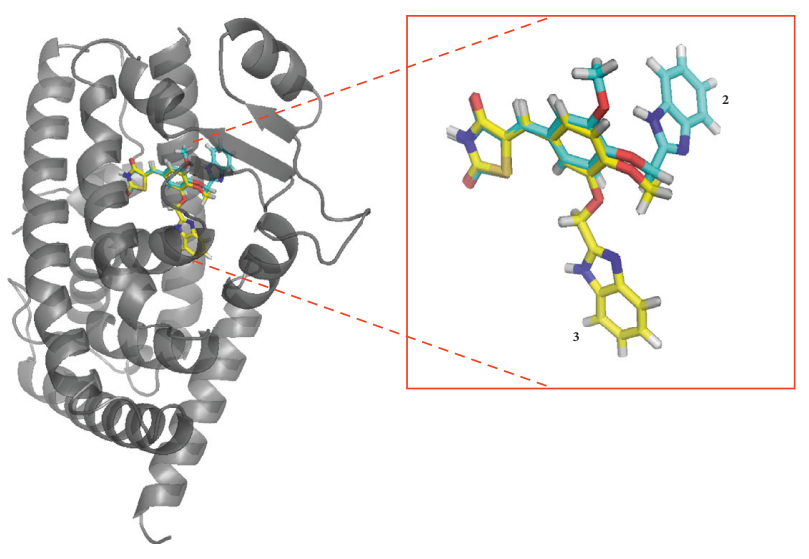

(a)

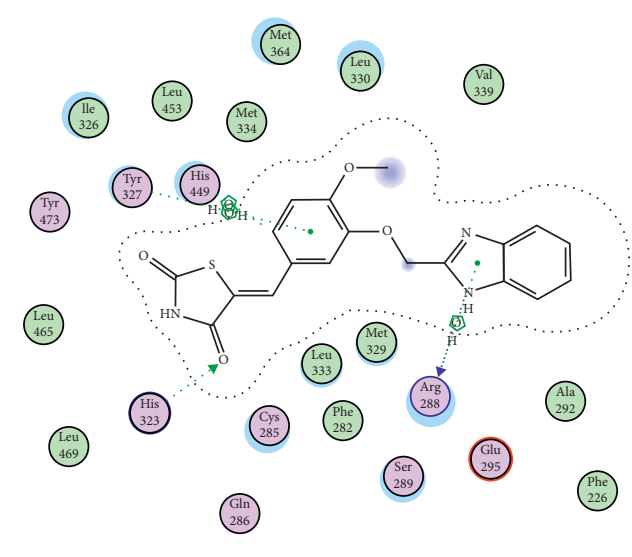

(b)

FIgURE 6: Comparison of the 3-D binding mode of regioisomers 2 and 3 (a) and 2-D map interaction of 3 with the PPAR $\gamma$ ligand site (b).

bonding network with His-323 [6]. p-Coumaric acid was also docked over PPAR $\gamma$ for comparative purposes with its inspired hybrids 1-3, showing less affinity than its bioisosteres, but maintaining the key polar interaction with His323 (Table 1). Validation of docking yielded an RMSD value of $0.433 \AA$. MOE [14] and Pymol version 1.7.4 were employed for visualization.

Hybrids $\mathbf{1}$ and $\mathbf{2}$ assume a similar conformation within the PPAR $\gamma$ ligand binding site mediated by hydrogen bonds with His-323 and $\pi$-sp ${ }^{3}$ interactions with His-449 (Figure 5).

Compound 3 (obtained from isovanillin) displayed a different conformation than its regioisomer 2 (obtained from vanillin). Although the thiazolidine-2,4-dione heterocycle was correctly oriented to interact with the His-323, the part of the benzimidazole ring was adapted to the side arm of the PPAR cavity, displaying several extra interactions with Arg-288, His-449, and Tyr-327 (Figure 6).

Both molecular docking scores (binding energies) and calculated affinities $(\mathrm{Ki})$ correspond to the performance of heterocycles 1-3, $p$-coumaric acid, and rivoglitazone in the in vitro and in vivo pharmacological tests (Table 1), suggesting that chemoinformatic simulations are very useful in drug discovery, to explain the potential mode of action of bioactive compounds.

\section{Conclusion}

In summary, three hybrids composed of benzimidazole and thiazolidine-2,4-dione have been synthesized, offering the following advantages over current antidiabetic glitazone drugs: preparation in fewer steps, use of safe and nontoxic raw materials (generally recognized as safe aldehydes: vanillin, isovanillin, and 4-hydroxybenzaldehyde), and comparable antihyperglycemic action. Hybrid bioisosteres 1-3 significantly augmented the mRNA expression of PPAR $\gamma$ and GLUT-4 greater than pioglitazone and in vivo reduced blood glucose concentration with antihyperglycemic effect linked to insulin sensitization mode of action.

\section{Data Availability}

The data used to support the findings of this study are included within the article and also available from the corresponding author upon request.

\section{Disclosure}

E. A. Domínguez-Mendoza is a PRODEP-SEP postdoctoral fellow (511-6/18-6769).

\section{Conflicts of Interest}

The authors declare that there are no conflicts of interest regarding the publication of this paper.

\section{Acknowledgments}

This work was financed by the "Consejo Nacional de Ciencia y Tecnología” (CONACYT) project no. 253814 (Ciencia Básica, 2015) granted to G. Navarrete-Vázquez. The authors also appreciate the support of "Laboratorio de Química Farmacéutica, Facultad de Farmacia, UAEM" and "Laboratorio 
Divisional de Biología Molecular, UAM-I" for providing some research supplies for this study.

\section{References}

[1] S. S. Schwartz, S. Epstein, B. E. Corkey, S. F. A. Grant, J. R. Gavin 3rd, and R. B. Aguilar, "The time is right for a new classification system for diabetes: rationale and implications of the $\beta$-cell-centric classification schema," Diabetes Care, vol. 39, no. 2, pp. 179-186, 2016.

[2] S. Hidalgo-Figueroa, S. Estrada-Soto, J. J. Ramírez-Espinosa et al., "Synthesis and evaluation of thiazolidine-2,4-dione/ benzazole derivatives as inhibitors of protein tyrosine phosphatase 1B (PTP-1B): antihyperglycemic activity with molecular docking study," Biomedicine \& Pharmacotherapy, vol. 107, pp. 1302-1310, 2018.

[3] M. Á. Herrera-Rueda, H. Tlahuext, P. Paoli et al., "Design, synthesis, in vitro, in vivo and in silico pharmacological characterization of antidiabetic N-Boc-L-tyrosine-based compounds," Biomedicine \& Pharmacotherapy, vol. 108, pp. 670-678, 2018.

[4] K. R. A. Abdellatif, W. A. A. Fadaly, G. M. Kamel, Y. A. M. M. Elshaier, and M. A. El-Magd, "Design, synthesis, modeling studies and biological evaluation of thiazolidine derivatives containing pyrazole core as potential anti-diabetic PPAR- $\gamma$ agonists and anti-inflammatory COX-2 selective inhibitors," Bioorganic Chemistry, vol. 82, pp. 86-99, 2019.

[5] Y.-H. Peng, M. S. Coumar, J.-S. Leou et al., "Structural basis for the improved potency of peroxisome proliferator-activated receptor (PPAR) agonists," ChemMedChem, vol. 5, no. 10, pp. 1707-1716, 2010.

[6] H. Rajapaksha, H. Bhatia, K. Wegener, N. Petrovsky, and J. B. Bruning, "X-ray crystal structure of rivoglitazone bound to PPAR $\gamma$ and PPAR subtype selectivity of TZDs," Biochimica et Biophysica Acta (BBA)-General Subjects, vol. 1861, no. 8, pp. 1981-1991, 2017.

[7] V. Amalan, N. Vijayakumar, D. Indumathi, and A. Ramakrishnan, "Antidiabetic and antihyperlipidemic activity of $p$-coumaric acid in diabetic rats, role of pancreatic GLUT 2: in vivo approach," Biomedicine \& Pharmacotherapy, vol. 84, pp. 230-236, 2016.

[8] A. Abdel-Moneim, S. M. A. El-Twab, A. I. Yousef, E. S. A. Reheim, and M. B. Ashour, "Modulation of hyperglycemia and dyslipidemia in experimental type 2 diabetes by gallic acid and p-coumaric acid: the role of adipocytokines and PPAR $\gamma$," Biomedicine \& Pharmacotherapy, vol. 105, pp. 1091-1097, 2018.

[9] G. Kaur, M. Kaur, and O. Silakari, "Benzimidazoles: an ideal privileged drug scaffold for the design of multitargeted antiinflammatory ligands," Mini-Reviews in Medicinal Chemistry, vol. 14, no. 9, pp. 747-767, 2014.

[10] O. O. Ajani, D. V. Aderohunmu, C. O. Ikpo, A. E. Adedapo, and I. O. Olanrewaju, "Functionalized benzimidazole scaffolds: privileged heterocycle for drug design in therapeutic medicine," Archiv der Pharmazie, vol. 349, no. 7, pp. 475-506, 2016.

[11] E. Hernández-Núñez, H. Tlahuext, R. Moo-Puc, D. Moreno, M. O. González-Díaz, and G. N. Vázquez, "Design, synthesis and biological evaluation of 2-(2-Amino-5(6)-nitro-1H-benzimidazol-1-yl)- $N$-arylacetamides as antiprotozoal agents," Molecules, vol. 22, no. 4, p. 579, 2017.

[12] B. Colín-Lozano, S. Estrada-Soto, F. Chávez-Silva et al., "Design, synthesis and in combo antidiabetic bioevaluation of multitarget phenylpropanoic acids," Molecules, vol. 23, no. 2, p. 340, 2018.
[13] A. Giacoman-Martínez, F. Alarcón-Aguilar, A. Zamilpa et al., "Triterpenoids from Hibiscus sabdariffa L. With PPAR $\delta / \gamma$ dual agonist action: in vivo, in vitro and in silico studies," Planta Medica, vol. 85, no. 5, pp. 412-423, 2019.

[14] Molecular Operating Environment (MOE), Computer-Aided Molecular Design, Chemical Computing Group ULC, Montreal, QC, Canada, 2019, http://www.chemcomp.com.

[15] A. Romero-Castro, I. León-Rivera, L. C. Ávila-Rojas, G. Navarrete-Vázquez, and A. Nieto-Rodríguez, "Synthesis and preliminary evaluation of selected 2-aryl-5(6)-nitro- $1 \mathrm{H}$ benzimidazole derivatives as potential anticancer agents," Archives of Pharmacal Research, vol. 34, no. 2, pp. 181-189, 2011.

[16] R. E. Soccio, E. R. Chen, M. A. Lazar, and M. A. Lazar, "Thiazolidinediones and the promise of insulin sensitization in type 2 diabetes," Cell Metabolism, vol. 20, no. 4, pp. 573591, 2014.

[17] S. Sugii, P. Olson, D. D. Sears et al., "PPAR $\gamma$ activation in adipocytes is sufficient for systemic insulin sensitization," Proceedings of the National Academy of Sciences, vol. 106, no. 52, pp. 22504-22509, 2009.

[18] S. Kanda, R. Nakashima, K. Takahashi et al., "Potent antidiabetic effects of rivoglitazone, a novel peroxisome proliferator-activated receptor- $\gamma$ agonist, in obese diabetic rodent models," Journal of Pharmacological Sciences, vol. 111, no. 2, pp. 155-166, 2009. 

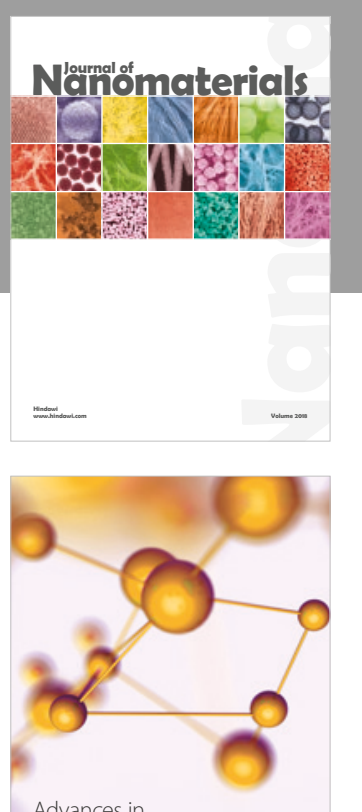

Physical Chemistry
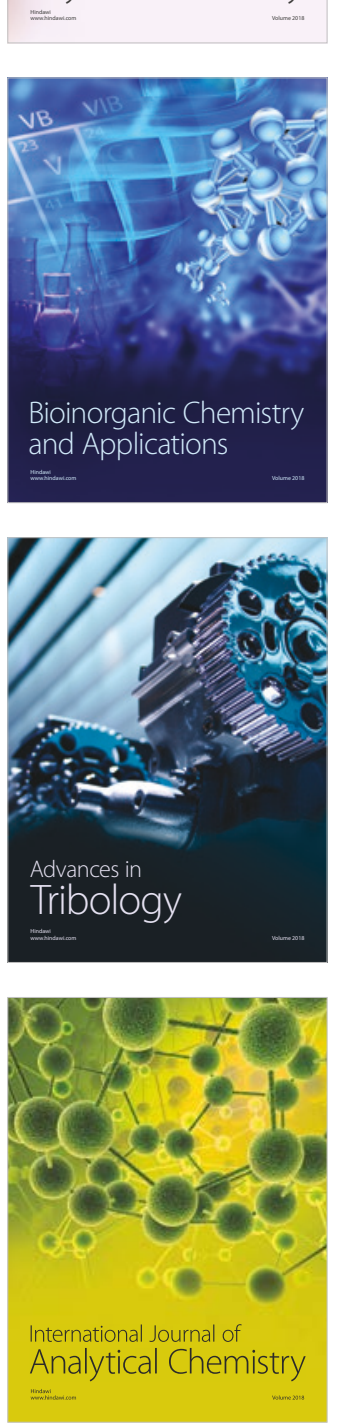

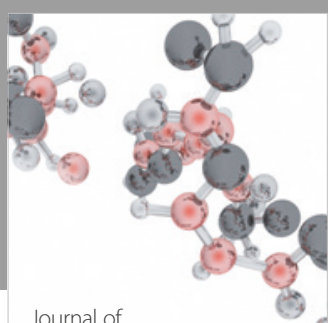

Analytical Methods

in Chemistry

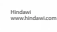

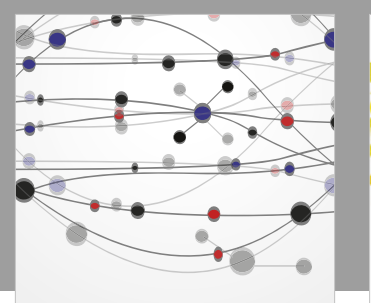

The Scientific World Journal

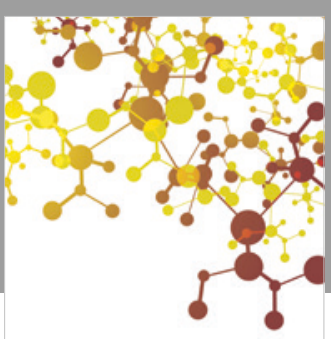

Journal of

Applied Chemistry
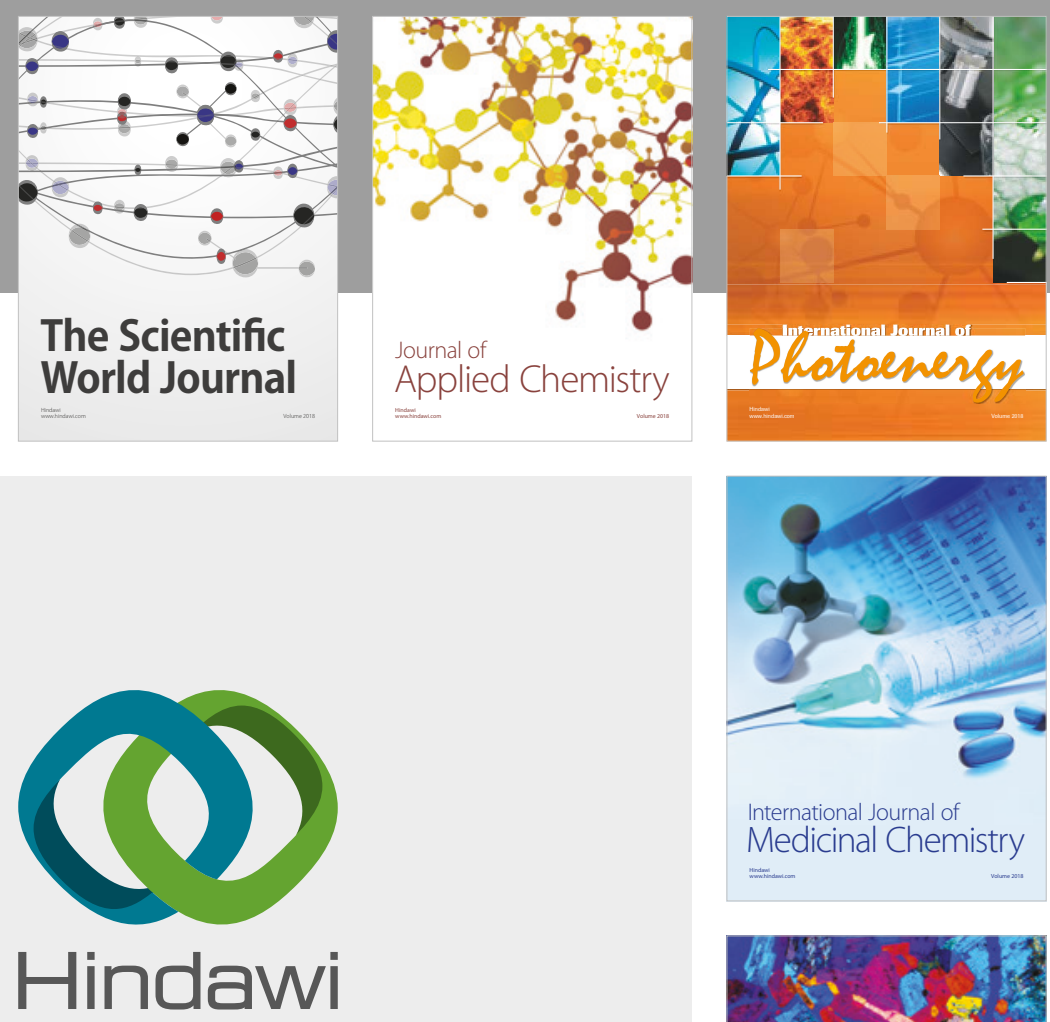

Submit your manuscripts at

www.hindawi.com

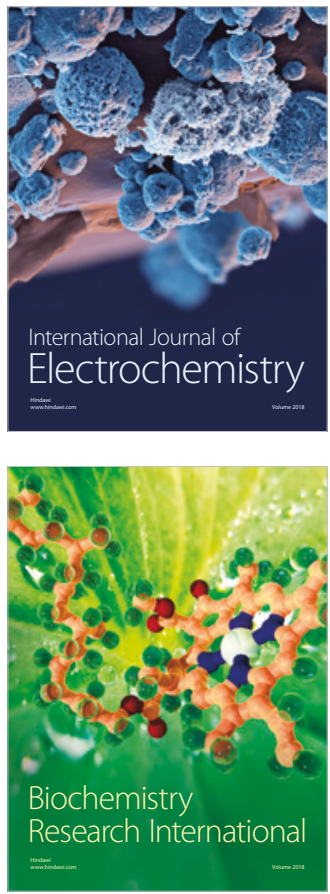